\title{
Humanoid Robots: Useful or Useless?
}

Dr R C Seals

Department of Electrical, Electronic \& Computer Engineering, University of Greenwich

\begin{abstract}
The potential usefulness of a humanoid robot (Robothespian) was investigated by a group of six MSc students, who chose to use this system for one of their oral assignments. A variety of methodologies was used by the students, ranging from treating the Robothespian mostly as a machine to engaging with it in an apparently fully-interactive live conversation. The humanoid robot investigation proved to be an interesting and stimulating approach, but one which did have problems: there was only one user interface (touch-screen display) available and it was quite slow to use.
\end{abstract}

\section{Introduction}

At the end of the 2013/14 academic year, the Faculty of Engineering and Science invested in a humanoid robot called Robothespian (Engineering Arts Ltd., 2015); see Figure 1. This system had been promoted as a mechanism for interacting with human audiences and increasing publicity for the operating organisation. It had many other additional uses, particularly in the area of human-machine interfacing (Technopia Dictionary, 2010); it also seemed to offer some intriguing possibilities in the educational environment: since humans led or directed the majority of education, if a human-like machine existed (Adams et al, 2000), what might be its potential in an educational context?

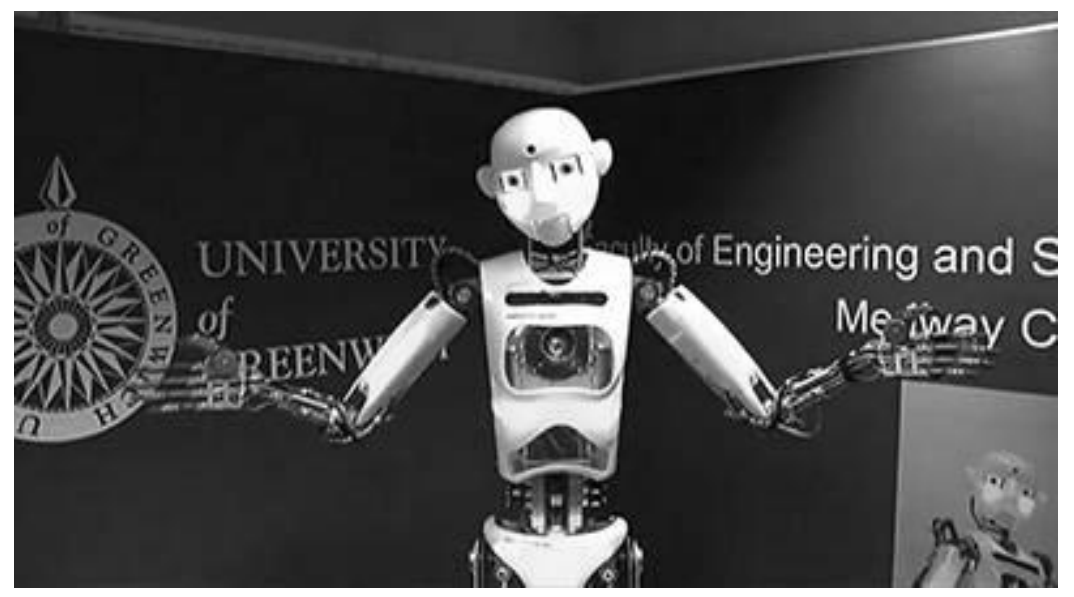

Figure 1: The University of Greenwich Robothespian

\section{The experimental conditions}

During the first term of $2014 / 15$, a decision was made to explore some of the capabilities of the Robothespian in the education environment, to see how effective, or possibly ineffective, it might be. If the Robothespian were to be used in a university education context, then it would be interacting with human students, and so the obvious first step was to consider how it might (easily) be incorporated into a real, live, student-based activity. It was also decided that such an investigation should be for a real assessment through which students would 
collect marks towards a course grade. As, therefore, marks were to be involved, the seriousness of using the Robothespian became apparent. So, rather than requiring all of a cohort of twenty-five MSc students to use the Robothespian, the tutor offered the students the choice between the humanoid and a PowerPoint for their delivery of an audio-visual presentation for a course called Multiple Technology Integration, part of a suite of MSc Programmes within the department of Electrical, Electronic \& Computer Engineering in the Faculty of Engineering and Science. The purpose of the assessment was to provide the students with the experience of creating a self-timed, audio-visual presentation on a technical matter. The students were not to give a live presentation, but incorporate their words into visual media. Previously, such approaches as PowerPoint and YouTube videos had been the proffered options, for drawing out the best responses (Wilson, 2010) and minimising opportunities for plagiarism. The Robothespian, the latest technology to be investigated, would be a novel choice.

Many of those studying on the Masters Programmes within Engineering are from overseas and represent wide variation in practical and laboratory experience and skill level. Multiple Technology Integration is designed to provide them with guided experience in using electronic laboratory equipment, in designing, implementing and testing electronic products and in reflecting on their designs and reporting on their achievements in various oral and written formats. The PowerPoint option guides them through the process of creating a selfcontained, ten-minute audio-visual presentation containing animated text and graphics; audio commentary is recorded to the slides and the whole thing then saved to a DVD or CD for submission. The aim of this particular assessment is two-fold: first, it introduces the student to the capabilities of PowerPoint; second, it provides them with a format that they can edit and change. Most students gain from it a satisfactory grasp of the capabilities of PowerPoint, but few seem to understand that they can change, re-work and edit the presentation (Khan, 2009). Students typically do the audio recording in a single take and submit all their hesitations, stumbles, errors and poor oral presentation techniques. Many do not recognise that they can listen to the presentation themselves and reflect on how it will appear to the assessor and the public in general.

PowerPoint thus deployed does serve as a less stressful introduction to live presentations and does require an understanding of how to interact with a live audience and the usefulness of a kinaesthetic approach. The Robothespian, on the other hand, seemed to offer a potentially better technique for getting students to reflect on the kinaesthetic elements of an oral presentation, as they would have to identify explicitly the face and body movements required and the specific points at which they should occur in the oral sequence. It offered the hope that students would be able to transfer from the robot to themselves their understanding of when and how to animate face and body when giving an oral presentation.

A possible interesting and novel addition to the main aim was the Robothespian's extra communication channel: a controllable colour display to the face and body, a dimension not readily available to humans during oral presentations!

Those students who chose to use PowerPoint were required to create a ten-minute, selftimed, audio-visual presentation on the design of a printed circuit board (PCB) that had to be saved to a CD-ROM or DVD. Those who chose to use the Robothespian had to create a 
YouTube video using the Robothespian in some way as part of an oral presentation on the design and implementation of a PCB. Six students (Gazir 2014, Shariff 2014, Rodange 2014, Azeez 2014, Nasir 2014, Vitor 2014) from the cohort of twenty-five chose to use the Robothespian: a sufficiently large part of the cohort to provide some useful feedback.

The entire cohort had prior experience of the creation of a self-timed, audio-visual PowerPoint, but none had previously come across the use of a humanoid like the Robothespian. All of them were therefore introduced to it, shown how it was programmed and then left to make a free choice of whether and how they would use it.

\section{Using the Robothespian}

Although the programming interface for the Robothespian was fairly simple and intuitive, it was also quite slow to use, via a touch screen provided with the robot. It had a text-tospeech converter for creating effective and understandable narration. Additionally, there were pre-programmed finger, hand, arm, head and upper body movement sequences (the bottom half of Robothespian was just cosmetic and not programmable), as well as body colour changes and eye variations. The combination of spoken word, movements and colour were sequenced as in a music score, with each type of movement on a separate stave. Although this provided flexibility and was not too difficult when creating a presentation for the Robothespian, it did make editing a previously-entered score laborious and time-consuming. Other more efficient interfaces for programming the robot were available, but there was insufficient time to train the students in how to use them. The result was that, although the spoken word was relatively easy to create, the association of finger-, hand-, arm-, body-, head- and eye-movements with precise parts of the narration tended to be fairly random.

No constraints or directions were imposed on the six students, who were left to decide themselves, individually, how they would use the robot and how long their presentations would be. The grading of the assessments was to be based on the interest generated and the audio-visual interaction; since the volunteers had all been assured that they would not be penalised for using the Robothespian, they did trust the tutor on this point.

Unfortunately for this activity, the Robothespian had been scheduled to take part in a regional TV local news programme (FES Engineering, 2014), which meant that, part way through the week available for the students, the robot was moved from its usual location and then afterwards hastily re-assembled in a noisy machine workshop area so that the students could complete their presentations. For those students who completed the presentation immediately, this was not an issue, but an allowance for background noise had to be made for the two students who left it a little late.

\section{Outcomes}

As the students had only the relatively short period of one week for this activity, it was not surprising that all the Robothespian presentations were short, ranging between one and two minutes. Much more interesting was the wide range of approaches taken by this small group of students in using this novel technology, as summarised in Table 1. 
Table 1: Summary of Robothespian Presentations

\begin{tabular}{|c|c|c|c|c|c|}
\hline Student & $\begin{array}{l}\text { Length } \\
\text { (s) }\end{array}$ & $\begin{array}{l}\text { Robot treated } \\
\text { as 'living'. }\end{array}$ & $\begin{array}{l}\text { Robot interaction } \\
\text { with the student }\end{array}$ & $\begin{array}{l}\text { YouTube } \\
\text { Views }\end{array}$ & $\begin{array}{l}\text { Special } \\
\text { features }\end{array}$ \\
\hline $\begin{array}{l}\text { [Gazir } \\
\text { 2014] }\end{array}$ & 118 & Yes & $\begin{array}{l}\text { The student is not } \\
\text { visible. The robot } \\
\text { speaks as if alive } \\
\text { and a friend. }\end{array}$ & 43 & $\begin{array}{l}\text { A normal } \\
\text { presentation. }\end{array}$ \\
\hline $\begin{array}{l}\text { [Shariff } \\
2014]\end{array}$ & 59 & $\begin{array}{l}\text { Partly. The } \\
\text { student is } \\
\text { shown starting } \\
\text { the robot. }\end{array}$ & $\begin{array}{l}\text { Initially, the student } \\
\text { speaks to camera, } \\
\text { introduces the robot } \\
\text { and then moves out } \\
\text { of view. }\end{array}$ & 61 & $\begin{array}{l}\text { All movement } \\
\text { stops after } 39 \\
\text { seconds and, at } \\
60 \text { seconds, } \\
\text { everything stops. }\end{array}$ \\
\hline $\begin{array}{l}\text { [Rodange } \\
\text { 2014] }\end{array}$ & 130 & $\begin{array}{l}\text { Yes. Robot } \\
\text { dressed with } \\
\text { scarf to become } \\
\text { more lifelike. }\end{array}$ & $\begin{array}{l}\text { The student holds a } \\
\text { conversation with } \\
\text { the robot. Some } \\
\text { questions are also } \\
\text { asked that are } \\
\text { answered by the } \\
\text { student. }\end{array}$ & 69 & $\begin{array}{l}\text { Presentation } \\
\text { scripted, with the } \\
\text { student } \\
\text { providing the } \\
\text { flexible timing } \\
\text { needed to make } \\
\text { it appear lifelike. }\end{array}$ \\
\hline $\begin{array}{l}\text { Azeez } \\
2014]\end{array}$ & 78 & $\begin{array}{l}\text { Partly. The } \\
\text { student is } \\
\text { shown starting } \\
\text { the robot. }\end{array}$ & $\begin{array}{l}\text { Initially, the student } \\
\text { speaks to camera, } \\
\text { introduces the robot } \\
\text { and then moves out } \\
\text { of view. }\end{array}$ & 61 & $\begin{array}{l}\text { Thanks given in } \\
\text { English and } \\
\text { another } \\
\text { language at the } \\
\text { end. }\end{array}$ \\
\hline $\begin{array}{l}\text { [Nasir } \\
2014]\end{array}$ & 92 & $\begin{array}{l}\text { Partly. The } \\
\text { student is } \\
\text { shown starting } \\
\text { the robot. }\end{array}$ & $\begin{array}{l}\text { Initially, the student } \\
\text { talks to camera and } \\
\text { then introduces the } \\
\text { robot. Good, but } \\
\text { then stops suddenly } \\
\text { and says goodbye. }\end{array}$ & 217 & $\begin{array}{l}\text { The robot } \\
\text { demonstrates } \\
\text { some of its } \\
\text { capability, such } \\
\text { as clucking like a } \\
\text { chicken. Says } \\
\text { goodbye in } \\
\text { several } \\
\text { languages. }\end{array}$ \\
\hline $\begin{array}{l}\text { [Vitor } \\
\text { 2014] }\end{array}$ & 119 & Yes & $\begin{array}{l}\text { Student and robot } \\
\text { interact and hold a } \\
\text { conversation. }\end{array}$ & 49 & $\begin{array}{l}\text { The robot } \\
\text { attempts a joke. }\end{array}$ \\
\hline
\end{tabular}

Note: All students were requested to avoid including any personal or identifying details within their YouTube videos.

\section{Conclusion}

Although this was a small sample and only a single isolated activity, it did seem that the use of a humanoid robot did have some potential in an educational environment. All the students treated the Robothespian at least in part as lifelike, with some taking care to achieve an enhanced impression of 'life'. It was also apparent by the shortness of the presentations that the touch screen user interface was not an effective method for deploying this system. 
Additionally, that there was only one Robothespian did restrict its use to small cohorts of students. However, as a promotional system, it was excellent and created significant interest wherever it was used.

\section{Reference list}

Adams, B., Breazeal, C. L., Brooks, R. and Scassellati, B. (2000) 'Humanoid Robots: A New Kind of Tool.' IEEE Intelligent Systems and their Applications, 15 (4), 25-31. ISSN 10947167

Azeez, J. (2014) Robothespian (Video). Available at: https://www.youtube.com/watch?v=R9GZ7rlVlaw (Accessed: 28 April 2015).

Engineering Arts Ltd. (2015) Robothespian. Available at:

http://www.techopedia.com/definition/12829/human-machine-interface-hmi (Accessed: 22 August 2015).

FES Engineering (2014) University of Greenwich, Faculty of Engineering and Science Engineering Facebook page (Video: See 13 November 2015 Robothespian BBC South East Today). Available at: https://www.facebook.com/pages/Engineering-at-the-University-ofGreenwich-Medway/1561205207431648?fref=nf (Accessed: 22 August 2015).

Gazir, L. (2014) Robothespian (Presentation video). Available at: https://www.youtube.com/watch?v=k5eDkO3DWJE (Accessed: 28 April 2015).

Khan, M. (2009) Blog: Reflection on Presentation. Available at: https://michaelkhan.wordpress.com/2009/09/22/reflection-on-presentation/ (Accessed: 24 August 2015).

Nasir, Y. (2014) Robothespian (Video). Available at: https://www.youtube.com/watch?v=y4Pfn6eJncY (Accessed: 28 April 2015).

Rodange, A. (2014) Robothespian (Presentation video). Available at: https://www.youtube.com/watch?v=rp6BsQN2sdw (Accessed: 28 April 2015).

Shariff, H. (2014) Robothespian (Presentation video). Available at: http://youtu.be/HrwEwxsaug> [Accessed: 28 April 2015).

Technopia Dictionary (2010) Available at:

http://www.techopedia.com/definition/12829/human-machine-interface-hmi (Accessed: 22 August 2015).

Vitor, J. (2014) Robothespian (Video). Available at: http://youtu.be/l9p-2s8NUZc (Accessed: 28 April 2015). 
Wilson, J.A.J. (2010) 'Getting the best out of your students through cultural appreciation: multiculturalism in a "British" university business classroom setting.' Compass: The Journal of Learning and Teaching at the University of Greenwich, 2009 1 (1), 53-63. ISSN 20440081. 